\title{
Dialogic Change and the Practice of Inclusive leadership
}

\author{
Dr. Niels Agger-Gupta \\ School of Leadership Studies, Royal Roads University \\ 2005 Sooke Rd., Victoria, BC, Canada \\ Phone: 250-778-977-3012 \\ Email: naggergupta@royalroads.ca \\ Dr. Brigitte Harris \\ Faculty of Social and Applied Science, Royal Roads University \\ 2005 Sooke Rd., Victoria, BC, Canada \\ Phone: 250-391-2600 ext. 4467 \\ Email: brigitte.3harris@royalroads.ca
}




\section{Structured Abstract:}

Purpose: This chapter explored theories related to inclusive leadership, and the application of inclusion and collaboration principles in a master's-level leadership program.

Design/Approach: We reviewed the concept of inclusive leadership, its theoretical grounding in social construction, and the role of collaboration and dialogue in learning, creativity, and what has been called, "dialogic change" in creating an inclusive culture. The application of four principles - leadership as engagement, engaged scholarship, orientation to possibility, and learning as transformation — have been critical to the practices of the authors as leadership educators and in teaching leadership.

Findings: Inclusive leadership practices can have a dramatic positive impact on employee engagement, organizational culture and, ultimately, on organizational effectiveness. Moreover, inclusive leaders can effectively navigate through a context of volatility, uncertainty, complexity, and ambiguity, through engaging those affected by these issues.

Social Implications: Universities play a key role in making the world a better place by educating future leaders to work effectively and respectfully with others by fostering creative problem solving. When faculty and staff embrace inclusive leadership principles in their work together, they generate creativity, and improve their effectiveness. As leadership educators, we not only model inclusive leadership principles; we use them as a framework for our teaching.

Originality/Value of paper: Our leadership journey from theory to practice is of interest to leadership educators, scholars, and practitioners seeking to better understand and apply the concept of inclusive leadership in their particular settings. While our setting is Canadian, we argue the theoretical discussion and principles have broader application.

Keywords: Inclusion; post-heroic leadership; social construction; dialogic change; leadership education; generative metaphor.

Classification: Conceptual paper

[Maximum is 250 words in total (ours is 250 words). Please provide up to six keywords] 


\section{The turn toward inclusion}

Royal Roads University (RRU), in Victoria, British Columbia, Canada, was founded in 1996 to serve mid-career adults and focus on applied research. $R R U$ is distinguished by its use of adult education principles and practice-focused experiential learning. The University attracted faculty with similar pedagogical/androgogical interests (Knowles, Holton, \& Swanson, 2005), and students commonly described their learning experience at RRU as "life-changing” (Agger-Gupta \& Etmanski, 2014; Harris \& Walinga, 2016).

In 2012 three faculty members, curious about what characterized teaching and learning at RRU, held a series of consultations to which all members of the university community were invited. The process brought together faculty, staff from the library, IT services, registrar's office, student services, and students to share perspectives about RRU's essential learning and teaching elements and practices. The result was a white paper on RRU's learning and teaching model (LTM) (Hamilton, Márquez, \& Agger-Gupta, 2013). As important, however, was that the process built a community identity, pride in the University and engaged people in discussions about what matters to them.

Included in the University's 2014 -15 academic plan, the LTM has had a prominent role in the direction of the University and has inspired faculty, staff, and student inquiries into aspects of their own practices. Many of these studies were recently published in a book, Engaging Students in Life-Changing Learning: The Royal Roads University Learning and Teaching Model in Practice (2016). This process has led to more projects, research, and excitement about current and future directions at RRU. The inclusive process increased the capacity of the University to serve its mission and built new relationships across the University, all with the aim of helping students succeed.

Ours is a story of inclusive leadership, of people co-creating and leading from wherever they are in an organization. We are two leadership educators. Inclusive leadership approaches and practices guide how we work with colleagues and students as well as our teaching of leadership. This chapter examines the theoretical underpinnings of inclusive leadership, and the role of social construction and dialogic change in creating an inclusive organizational culture. We also describe four key principles based on inclusion and dialogic processes that provide a foundation for our practice of inclusive leadership.

Several years ago, faculty and staff at the School of Leadership Studies embarked on a series of facilitated dialogues that aimed to bring us together as a team and to find the commonalities in our perspectives on leadership (Harris \& Agger-Gupta, 2015). While inclusive leadership approaches have long been part of our practice, this process identified the inclusive leadership values and practices we held in common, and the robustness of the approach to build relationships, mediate divisive forces, and increase our capacity to serve our students. Our leadership journey from theory to practice is of interest to leadership educators, scholars, and practitioners seeking to better understand and apply the concept of inclusive leadership in their particular settings. While the setting is Canadian, the theoretical discussion and principles have application beyond Canada, as study on inclusion in organizations in Australia, China, India, Mexico, and the US demonstrated (Prime \& Salib, 2014). 


\section{What is Inclusion in Organizations?}

Sally Helgesen, first to write about inclusion as a critical element of leadership, described it as, "draw[ing] on leadership skills from throughout the organization, while at the same time providing opportunities for people to develop those skills" (1995, p.110). Inclusion is about sharing ownership of issues, opportunities, and processes, and includes a shared implementation of co-created solutions. This shared ownership is very different from organizational stakeholders acquiescing ("buying-in") to a leader's process or solution, and is what Brenda Zimmerman, Paige Reason, Liz Rykert, Leah Gitterman, Jennifer Christian, and Michael Gardam (2013), in a healthcare context, called, “front-line ownership”.

Keimei Sugiyama, Kevin Cavanagh, Chantal van Esch, Diana Bilimoria, and Cara Brown (2016) framed inclusion as, "enhancing the relational self-awareness necessary to consider multiple identities and perhaps even intersectionality of identities in meeting belonging and uniqueness needs” (p. 256). Thus, the key benefit of inclusive leadership is in "relating to others in a way that makes them feel valued for their unique talents and backgrounds” (p. 257). Similarly, Jennifer Thorpe-Moscone’s (2015) study of inclusive leadership in Canada identified that feeling valued as a part of a team led to a sense of belongingness, which, in turn, led employees to feel valued for their uniqueness. These two characteristics were essential to employees feeling included. Sugiyama et al. (2016) found that leadership development needs to balance building relationships and accomplishing business objectives but, critically, one cannot be done without the other (p. 258).

So, if inclusion and building relationships across an organization are an essential part of leadership, leadership theory needs to reflect these ideas. Joseph Raelin (2003; 2006; 2016) contrasted a historical model of leadership as dispassionate, autocratic control with "leadership-as-practice," or the concept of "leaderfulness". This concept proposed leadership in an effective organization necessarily occurs among all members, who work together collaboratively, and compassionately, as a collective (2003, pp. 14-18). A "leaderful” organization encourages leadership from anywhere in the organization. In this conception, leadership is about agency, and becomes a shared and expected aspect of organizational or community citizenship (Raelin, 2014; 2016). "Collaborative leaders realize that everyone counts; every opinion and contribution sincerely matters” (Raelin, 2003, p. 16). Steve Rayner (2009), who framed agency and inclusion from the perspective of learning, also understood leadership as inclusive, "involv[ing] every member of the learning community in some form of 'learning leadership"” (p. 439). He also noted "an inclusive leader aims to facilitate the transforming and transformative effect of learning in the work of making provision for the most vulnerable in the learning community” (p. 445). This turn toward inclusive leadership is about creating contexts that welcome the wisdom and engagement of all stakeholders, and away from autocratic, top-down direction.

Inclusion is also embedded in Marilyn Taylor's (2011) characterization of “post-conventional” and "postheroic" leadership discourse. Such leaders have "personal purpose and responsibility, are values-focused, and practice shared leadership and collaboration, authenticity, and transparency" (p. 189). Thus, leadership goes well beyond strategic decision-making, to advocating an inspirational purpose and, a profoundly respectful appreciation for and engagement of all organizational stakeholders across diversities (Quinn \& Thakor, 2014). The intention is to make the workplace a center of dignity, meaning, and community (Weisbord, 2012). Leaders, therefore, harness the hearts and minds of all organizational members, forging new directions by listening deeply, understanding and engaging others in dialogue to 
create shared meanings. Inclusive leadership strategies include motivating others through humble respect for their experiences and perspectives, supporting, requesting and sharing authentic feedback (Schein, 2013), and inspiring, coaching, and mentoring others to build understanding and competence (Quinn \& Thakor, 2014; Kouzes \& Posner, 2007). Thus, the turn from heroic leadership is simultaneously the turn toward inclusion as a core part of leadership.

\section{From individualism to relational and group constructs of innovation}

Lev Vygotsky (1986) demonstrated that knowledge is developed socially. He coined the term "proximal zone of development" to refer to the difference between what a child could accomplish on a test by him/herself, and the increased knowledge the child could demonstrate when in conversation with a trusted older student or teacher on the tested topic (p. 102). However, until relatively recently, the structure of assignments, courses, and evaluation methods have reflected the tacit assumption that invention and learning are private, asocial acts (LeFevre, 1986, p. 13). Similarly, conceptions of the individual heroic leader are based on an assumption that leadership, innovation, and education are solitary acts. Karen LeFevre (1986) attributed the origin of individualistic approaches to invention as the desired and ideal state to the Greek philosopher Plato. Plato’s The Phaedrus describes invention as a solitary, individual act of recall to the perfect state prior to birth (Plato \& Jowett, 2001; LeFevre, 1986). LeFevre argued that the belief that truth and knowledge is entirely within, and accessible only by purely individual efforts, has had a substantial impact on the creative act - and for scholarship as a whole - where the rewards for invention have traditionally focused on the individual. This individualistic way of thinking, said LeFevre, has dominated our models of intellectual thought and led to confusion between independent thinking and solitary thinking (thinking 'for' as opposed to 'by' yourself), even if teachers with the best of intentions believe they are encouraging self-reliance and self-expression (1986, pp.12-13).

The move to inclusive leadership through dialogic approaches reflects a change in thinking about innovation and change. LeFevre identified seven aspects of invention that are social and relational (1986, pp. 33-35). First, the 'self' that does the inventing is socially influenced, and even socially and culturally constituted (also see Gergen \& Gergen, 2008). Second, invention is done through language or other symbolic systems that are created and shared among a discourse community. Third, invention is built upon the foundation of knowledge accumulated from previous generations and "each creative act is given to another generation of thinkers who may dismiss, confirm, or build on it” (p.34). Fourth, an internal dialogue with an imagined other or an audience that supplies premises or beliefs may enable invention. Fifth, writers often use editors or others whose feedback comments support further creativity. Sixth, invention is powerfully influenced by professional or scholarly institutions, regulatory bodies, or governments, which set expectations, scope, and acceptable and unacceptable frames for invention (see, for example, Jane Jorgensen \& Frederick Steier's article on frames and framing, 2013). Seventh, the social context of the inventor (or writer) plays a large role in determining the reception or evaluation of the invention (LeFevre, 1986, pp. 33-35). The last two aspects of LeFevre's invention as a social act seem to echo Jürgen Habermas's “validity claim” of normative legitimacy for a communicative act, whereby a listener (or audience) needs to accept both the communication itself, and the speaker, as legitimate within a particular context, in addition to the other validity claims of comprehensibility, truthfulness (or honesty), and factual accuracy (1985, pp. 305-319). Like invention, leadership is relational and dialogic. 


\section{Dialogic Change and Inclusion}

Gervais Bushe and Robert Marshak (2015) describe organizational change as a socially-constructed process, in that "change” is essentially a re-alignment of how the key stakeholders see themselves and their perspectives on an issue. As organizational stakeholders become more skillful in reflection and considering alternatives to their original position, conversations can lead to new ideas more easily in organizations. Chris Argyris (1990) demonstrated organizations that created 'safe' spaces for dialogue were able to make progress in addressing issues and opportunities with greater consensus, while organizations in which workers and staff felt unsafe or unsupported in being authentic, or where bosses resented such openness, were unsuccessful in moving forward (Schein, 2015, pp xi-xii). Both alone (1990), and with his co-author, Donald Schön (1978), Argyris described 'defensive routines' within organizations that created "undiscussable” issues. Simply calling for 'openness' within an organization does not make it so, particularly when subordinates feel psychologically unsafe in speaking their minds in the presence of their bosses (Bushe \& Marshak, 2009). More recently, Bushe and Marshak (2015) identified 40 dialogic organizational development methods that help to create psychological safety and authentic dialogue, such as Open Space Technology (Owen, 2008), Interview Matrix (Harrison, 1999; Chartier, 2002; O’Sullivan, Corneil, Kuziemsky, \& Toal-Sullivan, 2015), and World Café (Brown \& Isaacs, 2005). In part, these approaches involve learning new ways to communicate, or 'think together,' including "suspending” one's initial reaction to what someone says, considering alternative explanations, and reflecting on one's own reactions, rather than blurting out knee-jerk response (Isaacs, 1999, p. 13458). William Isaacs argued that these dialogue strategies allowed for a greater number of ideas to surface, individuals had greater opportunity to qualify their comments and explain their thinking, and group consensus was more frequent. Frank J. Barrett, Gail Fann Thomas, \& Susan P. Hocevar (1995) described dialogue and relationship as the heart and core of any change process:

For it is through patterns of discourse that we form relational bonds with one another; that we create, transform, and maintain structure; and that we reinforce or challenge our beliefs. The very act of communicating is the process through which we constitute experience. (p. 353)

If conversations build relationships and construct our subjective and intersubjective worlds, then being a participant in the ongoing discourse of an organization or community is an essential part of being seen to be - and feeling oneself to be - included.

\section{The Turn to Social Construction in Leadership}

The turn to social construction (see Berger \& Luckman, 1967; Gergen \& Gergen, 2008) is another way of understanding the dialogical nature of social invention. The dialogue between and among peers in a safe environment is how new concepts take root. Social relations and language are context-based and interdependent:

The meaning of "strike" and "home run" do not only depend on the rules of baseball talk, but on their function within a form of life that includes balls, bats, bases, fields, players, umpires, hotdogs, and so on. Broadly speaking, the ways in which we walk, talk, laugh, cry, worship, engage in warfare, and virtually everything else we do, become sensible — or not - by virtue of collaborative action.

(Gergen \& Hersted, 2016, p. 182)

According to Bushe and Marshak (2015), cultures, and whole worlds are built based on collective meaning making, and that different metaphors produce a resulting dialogue where personal and organizational change are simultaneous. They suggest one or more of three change processes take place 
in dialogic change. First, a disruption in the normal socially-constructed reality stimulates or results in a more complex re-organization of that reality (see, for example Prigogine \& Stengers, 1984). Second, a change to one or more core narratives takes place - for example, a change in purpose, vision, mission, who has influence or not, important challenges and opportunities, or normative behaviors in the organizational culture - resulting in new, socially-agreed upon narratives that support the new order. Third, a generative image or symbol is created that provides a new way of thinking about social interactions and the organization as a whole (Bushe \& Marshak, 2015, pp. 20-24). For example, the phrase, "sustainable development", is a generative image that, when introduced in 1987, led to new relationships between organizations and environmentalists (Bushe, 2013, p. 93). Gervais Bushe and Aniq F. Kassam (2005) found change efforts that developed such generative images were more likely to have long-term success).

In our experience, positive, inclusive change comes about from the collective wisdom of the stakeholders to the change, especially those who are going to be affected by it. Ultimately, any given change is negotiated through a learning process centered on the dialogue between parties who hold different models of reality in their minds as a result of their unique life experiences. Bushe and Marshak (2015) describe this emergent conversational process as "dialogic change," because it results in a socially-constructed new organizational reality that is first conceptualized and almost simultaneously developed as the new norm, through the conversation among stakeholders about an issue, problem, or opportunity (see, for example, Ford, 1999; Gergen \& Thatchenkerry, 1996). These conversations and inclusion in decision-making directly relate to the success of change initiatives. Good ideas can come from anyone, if one is willing to listen to the diverse voices, and recognize the power of articulated lived experience to describe new perspectives but recognizing the power of emergent new ideas requires letting go of rationally predetermined outcomes (Bush \& Marshak, 2015, p. 18). This inclusive leadership approach can have a dramatic impact on the kinds of stories people tell about their organization, on the organizational culture and climate of encouraging diverse perspectives, and, ultimately, on organizational effectiveness.

\section{Fostering inclusive leadership in leadership education}

The new understanding of leadership has implications for universities in their critical role of educating professionals. What should the role of universities be in the face of serious and seemingly intractable problems, including growing economic disparity, climate change, and a global context of volatility, uncertainty, complexity, and ambiguity, or VUCA (see, for example, Euchner, 2013). Michael Fullan and Geoff Scott (2006) argue that universities must prepare students to become leaders who can work effectively with others to solve the complex and divisive problems that confront the world (p. 42). In fact, if universities do not rise to this challenge, they risk becoming marginalized or even irrelevant. Implicit in their argument is the need for inclusive leaders who can work to harness the wisdom of others to solve problems. Given the need for inclusive leaders to address such problems, how should we, as leadership educators, teach and model inclusive leadership values and practices? In the School of Leadership Studies, faculty members engaged in dialogues over several years to identify commonly held values and principles that constitute the unifying foundation of our programs. These interlocking and overlapping inclusive principles are: leadership as engagement, engaged scholarship, orientation to possibility, and learning as transformation (Harris \& Agger-Gupta, 2015). These four principles serve as a generative image for the School, and have had a dramatic impact on our work. Each of these principles is defined 
below, and explicitly linked to the support and development of inclusive leaders engaged in dialogic change.

\section{Four principles for inclusion}

\section{Leadership as engagement}

Inclusive leaders help others to work together effectively, creating in followers both sense of belonging and that their unique contributions are recognized and valued (Sugiyama et al., 2016). This relational work entails leaders engaging others to work toward a common purpose, facilitating inclusive processes, and removing barriers. Including the people who will be impacted by or are responsible for implementing change is critical for creating a sense of ownership (Wheatley, 2006, p. 69). The principle of leadership as engagement implies the inclusive leadership behaviors of empowering others, and humility, e.g., seeking and listening to the input of others (Prime, \& Salib, 2014), acknowledging the need to learn about others' perspectives.

Leadership as engagement requires "social intelligence”, in which leaders engage in "humble inquiry", being curious about and seeking to understand the perspectives of others (Schein, 2013) and distinguishing what is known from what is assumed and what is unknown (Schein, 1997, p. 206). Inclusive and engaging leaders value their own ongoing and "emergent learning” (Taylor, 2011), with which they navigate unfamiliar or previously not experienced landscapes, issues, challenges and turbulence in their environments. Critically, they also support the development and learning of others. They help people to grow and thrive through creating opportunities for meaningful conversations, maintaining an orientation to possibility, and recognizing that change and learning are transformative experiences (Harris \& Agger-Gupta, 2015). In this way, they build an organization's capacity to respond effectively to the challenges it encounters (Senge, 1990).

\section{Engaged scholarship}

Our practice of "engaged scholarship" is an extension to knowledge creation of the principles of leadership for engagement. Engaged scholarship removes barriers between those who create knowledge (i.e., do research) and those served by knowledge creation (i.e., practitioners). Engaged scholars bring together people with different perspectives — primarily scholars and practitioners — to co-create knowledge (Barge, Jones, Kensler, Polok, Rianoshek et al., 2008). Diverse perspectives can foster “a much deeper understanding of a phenomenon" (Van de Ven, 2011, p. 43) than researchers or practitioners could achieve by themselves. Just as inclusive leaders seek to include a wide range of perspectives in problem-solving, learning and confronting new and emerging situations, engaged scholarship calls on scholars to practice inclusion of various stakeholders in research. Thus, scholar-practitioners need to invite those who are not normally part of the conversation to the table, and make this kind of leadership the organizational norm, creating opportunities for increased insight, positive connection, inclusion, and change (Wheatley, 2002; Woods, 2016, p. 81).

In engaged scholarship, students are also partners in knowledge creation, particularly in action research and service learning projects. Hillary Bradbury and Peter Reason (2003) characterize action research projects as: “(1) grounded in lived experience, (2) developed in partnership, (3) addressing significant problems, (4) working with, rather than simply studying, people, (5) developing new ways of seeing/theorizing the world, and (6) leaving infrastructure in [their] wake” (p. 155). Similarly, service 
learning involves real-world community or organizational projects as vehicles for learning, with benefit for students and their institutions and communities and/or organizations. These projects involve: (1) learning goals or outcomes for students, and the aim of benefitting a community; (2) collaboration of students, faculty/staff and community/organization members and/or community organizations and educational institutions; and, (3) critical reflection and assessment processes that document both meaningful learning and community outcomes (Felton \& Clayton, 2011).

Students in our programs engage in action research, and service learning in their masters' research. They engage stakeholders to plan and carry out an action research project within an organization, often the one in which the students work, to address an actual problem or opportunity of significance. We support our students in research that aims to make a positive difference in organizations, communities and professional groups. We work with our students as "co-creators of knowledge” (Fretz \& Longo, 2010, p. 317) and positive change, learning to apply inclusive and dialogic principles through an inquiry approach to problem solving. Through their research, our students learn the benefit of including diverse perspectives to generate new perspectives and solutions for social benefit. We see our students as cocreators of "an engaged academy", helping to increase both student engagement in their learning and university engagement in communities (Fretz \& Longo, 2010, p. 313).

\section{Orientation to possibility}

Inclusive leaders need to need to maintain an orientation to possibility, open to changing their minds through learning and dialogue. "When the leader is able to abide in ambiguity and not defend against the accompanying feelings of fear and anxiety, new opportunities for learning and creativity open up (Skjei, 2014, p. 218). Changing their thinking about barriers, and problems can help leaders become unstuck. For example, rather than fighting resistance, inclusive leaders welcome such differences as an opportunity to understand the diversity of perspectives involved in an issue (Allen, 2012, p. 71). Holman (2010) urges leaders to "call forth "what could be”” (p. 62) and use problems as "a doorway to opportunity” (p. 63). Thus, leaders can reframe perceived or actual barriers as motivators for creativity through moving beyond discouragement and blame to taking an evidence-informed basis for determining next steps (Adams, 2009). As leadership educators, we foster this orientation in our students as a means of developing leaders who can respond effectively in volatile and uncertain contexts (Euchner, 2013).

\section{Learning as transformation}

Inclusive leadership, and leadership education, requires an understanding of transformative learning. . Such learning goes beyond 'facts,' or “first order learning” (Bateson, 2000), to learning how to learn ("second-order learning") and an understanding of how inclusive values and relating to the world have an impact on learning ("third-order learning"). Thus, in addition to teaching knowledge and application of skills, we believe that leadership educators need to create a learning environment and activities in which students can engage in second- and third-order learning to enable them to "transform themselves and society" (UNESCO, 2008). Second- and third-order learning are also characteristic of "emergent learning” (Taylor, 2011), which helps leaders "to engage constructively with the unfamiliar, and to adapt and learn in a continuously emergent context” (p. 27). Such transformative learning challenges leaders to be inquirers to create the potential of seeing things anew, and even, "know how to construct new knowledge when faced with problems for which there is no known solution or even for which there is no known conceptual lens (Raelin, 2006, p. 7). 
We have more than anecdotal evidence that our students experience "transformative learning” (Mezirow et al., 2000). Jennifer Walinga and Brigitte Harris (2016) examined the learning narratives of 45 students in four RRU masters-level programs. They documented students' transformative learning processes from the initial disorienting dilemma to the emergence of new and enduring state of insight or consciousness. These transformations changed how students learned and had lasting application in both their professional and personal lives. As leadership educators, we have come to believe that learning with the specific goals of individual and collective transformation is critical to inclusive leadership, but we also see the challenges of doing so, since transformative change requires students, and sometimes faculty, to accept and adopt emergence, and letting go of preconceived outcomes (see for example, Bushe, 2013).

\section{Conclusion}

This chapter discussed "the turn to inclusive leadership" to address the challenges that confront leaders. It examined the theoretical grounding of social construction in the shift from individualism to relational and group constructs of innovation as well as the role of dialogic change in creating an inclusive culture. We also described four key principles, which were the outcomes of the School of Leadership Studies' inclusive and dialogic processes.

While we both work to practice inclusive leadership and teach it in our graduate programs, we recognize this approach to leadership is not easy. In our own, and in our students,' applied research we have witnessed frequent organizational churn, resulting in changed priorities and strategic direction that decreases engagement and the withdrawal of support for these projects. Stakeholders in such research may feel change is necessary and want to be consulted, but find it difficult to take the time to engage in dialogue. Yet, when we ask our graduates about the most valuable learning experiences in our program, the answer is consistently that the research project provided their richest learning.

The literature tells us that inclusive leadership focused on dialogic change results in better outcomes (Bushe \& Marshak, 2015; Helgesen, 1995), increased ownership (Wheatley, 2006; Zimmerman et al., 2013) and a sense of belonging and being valued (Sugiyama et al., 2016). Our experiences of inclusive leadership, and our students' feedback tell us that, despite the challenges, the outcomes are worth it. 


\section{Acknowledgements}

The authors would like to thank their colleagues in the School of Leadership Studies at Royal Roads University for the generative dialogue - including numerous disagreements - over the last five years. These have led to our organization's inclusive and collaborative culture culture that has sparked our understanding and teaching of leadership. We would also like to thank the many Leadership students for countless stimulating dialogues that have also helped forge our leadership understandings, and with whom we hope we have demonstrated a continuous orientation to possibility. As well, we would like to thank our respective partners for their support and encouragement. 


\section{References}

Adams, M. G. (2009). Change your questions, change your life: 10 powerful tools for life and work (2nd ed.). San Francisco, CA: Berrett-Koehler Publishers and Books24x7, Inc.

Agger-Gupta, N., \& Etmanski, C. (2014). The paradox of transformative learning among mid-career professionals. International Journal of Adult Vocational Education and Technology (IJAVET), 5(1), 35-47. http://doi.org/10.4018/ijavet.2014010104

Allen, K. (2012). Dancing on a slippery floor: Transforming systems, transforming leadership. In C. Pearson (Ed.), The transforming leader : New approaches to leadership for the twenty-first century (pp. 64-74). San Francisco, CA: Berrett-Koehler Publishers.

Argyris, C. (1990). Overcoming organizational defenses: Facilitating organizational learning. New York: Prentice Hall.

Argyris, C., \& Schön, D. A. (1978). Organizational learning: A theory of action perspective (Later Printing). New York: Addison-Wesley.

Barge, J.K., Jones, K.E., Kensler, M., Polok, N., Rianoshek, R., Simpson, J.L., \& Schockley-Zalabak, P. (2008). A practitioner view toward engaged scholarship. Journal of Applied Communication Research, 36(3), 245-250.

Barrett, F. J., Thomas, G. F., \& Hocevar, S. P. (1995). The central role of discourse in large-scale change: A social construction perspective. The Journal of Applied Behavioral Science, 31(3), 352-372. http://doi.org/10.1177/0021886395313007

Bateson, G. (2000). Steps to an ecology of mind: Collected essays in anthropology, psychiatry, evolution, and epistemology (1st ed.). Chicago: University Of Chicago Press.

Berger, P. L., \& Luckmann, T. (1967). The social construction of reality: A treatise in the sociology of knowledge. New York: Anchor Books.

Bradbury, H. \& Reason, P. (2003). Action research: An opportunity for revitalizing research purpose and practices. Qualitative Social Work 2,(2), 155-175. doi: 10.1177/1473325003002002003

Brown, J., Isaacs, D., \& World Cafe Community. (2005). The world cafe: Shaping our futures through conversations that matter (eBook 1). Berrett-Koehler Publishers.

Bushe, G. R. (2013). Generative process, generative outcome: The transformational potential of appreciative inquiry. In D. L. Cooperrider, D. P. Zandee, L. N. Godwin, M. Avital, \& B. Boland (Eds.), Organizational generativity: The appreciative inquiry summit and a scholarship of 
transformation (Vol. 4, p. 89 - 113). Bingley, U.K.: Emerald Group Publishing Limited. Retrieved from http://www.gervasebushe.ca/Al_generativity.pdf

Bushe, G. R., \& Kassam, A. F. (2005). When is appreciative inquiry transformational? A meta-case analysis. The Journal of Applied Behavioral Science, 41(2), 161-181. http://doi.org/10.1177/0021886304270337

Bushe, G. R., \& Marshak, R. J. (2009). Revisioning Organization Development: Diagnostic and Dialogic Premises and Patterns of Practice. The Journal of Applied Behavioral Science, 45(3), 348-368. http://doi.org/10.1177/0021886309335070

Bushe, G. R., \& Marshak, R. J. (2015). Chapter 1: Introduction to the dialogic organization development mindset. In G. Bushe \& R. J. Marshak (Eds.), Dialogic organization development: The theory and practice of transformational change (pp. 11-32). San Francisco, CA: Berrett-Koehler Publishers.

Chartier, B. (2002). Tools for leadership and learning: Building a learning organization. Retrieved March 29, 2013, from http://managers-gestionnaires.gc.ca/tools-outils/tools_for_leadershiptrousse_du_leadership-eng.php

Euchner, J. (2013). Navigating the VUCA world: An interview with Bob Johansen. Research Technology Management, 56(1), 10-15.

Felten, P., \& Clayton, P. H. (2011). Service-learning. New Directions for Teaching and Learning, 2011(128), 75-84. doi:10.1002/tl.470

Ford, J. D. (1999). Organizational change as shifting conversations. Journal of Organizational Change Management, 12(6), 480-500.

Fretz, E.J., \& Longo, N.V. (2010). Students co-creating an engaged academy, pp. 313-335. In H. Fitzgerald, C. Burack, \& S. D. Seifer (eds.) Transformation in Higher Education: Handbook of Engaged Scholarship (vol. 1). East Lansing, MI: Michigan State University Press.

Fullan, M. \& Scott, G. (2006). Turnaround leadership. San Francisco, CA: Jossey-Bass. Retrieved from http://catalog.hathitrust.org/Record/005288094

Gergen, K. J., \& Gergen, M. M. (2008). Chapter 10: Social construction and research as action. In P. Reason \& H. Bradbury (Eds.), The SAGE Handbook of Action Research (pp. 159-171). London: SAGE Publications Ltd. Retrieved from http://srmo.sagepub.com/view/the-sage-handbook-ofaction-research/d16.xml

Gergen, K. J., \& Hersted, L. (2016). Chapter 9: Developing leadership as dialogic practice. In J. A. Raelin (Ed.), Leadership-as-Practice: Theory and Application. New York: Routledge. 
Gergen, K. J., \& Thatchenkery, T. J. (1996). Organization Science as Social Construction: Postmodern Potentials. The Journal of Applied Behavioral Science, 32(4), 356-377. http://doi.org/10.1177/0021886396324002

Habermas, J. (1985). The theory of communicative action, volume 1: Reason and the rationalization of society. (T. McCarthy, Trans.). Boston, MA: Beacon Press.

Hamilton, D., Marquez, P., Agger-Gupta, N., Grundy, S., Veletsianos, G., Forssmann, V., \& LeGault, M. (Eds.). (2016). Engaging students in life-changing learning: The Royal Roads University learning and teaching model in practice. Victoria, BC, Canada: Royal Roads University. Retrieved from https://learningandteachingmodel.pressbooks.com/

Hamilton, D., Márquez, P., \& Agger-Gupta, N. (2013). RRU Learning \& Teaching Model. Retrieved October 20, 2013, from http://media.royalroads.ca/media/marketing/viewbooks/2013/learningmodel/?pageNumber=1

Harris, B., \& Agger-Gupta, N. (2015). The long and winding road: Leadership and learning principles that transform. Integral Leadership Review, (January-February).

Harrison, T. (1999, February 22). Instructions for interview matrix. [manual]. Retrieved from http://www.chriscorrigan.com/facilitation/matrice_e.pdf

Helgesen, S. (1995). The web of inclusion. New York: Doubleday Business.

Holman, P. (2010). Engaging emergence: Turning upheaval into opportunity. San Francisco: BerrettKoehler.

Isaacs, W. (1999). Dialogue: The Art Of Thinking Together (1st ed.). New York: Crown Business.

Jorgenson, J., \& Steier, F. (2013). Frames, framing, and designed conversational processes: Lessons From the world café. The Journal of Applied Behavioral Science, 49(3), 388-405. http://doi.org/10.1177/0021886313484511

Knowles, M. S., Holton, E. F., \& Swanson, R. A. (2005). The Adult learner: The definitive classic in adult education and human resource development (6th ed.). Oxford, UK: Butterworth-Heinemann / Routledge.

Kouzes, J. M., \& Posner, B. Z. (2007). The leadership challenge, fourth edition (4th ed). San Francisco, Calif: Jossey-Bass : J. Wiley.

LeFevre, K. B. (1986). Invention As a Social Act. Carbondale: Southern Illinois University Press. 
Mezirow, Jack (2000). Learning as transformation: Critical perspectives on a theory in progress. San Francisco: Jossey-Bass/Wiley.

O'Sullivan, T. L., Corneil, W., Kuziemsky, C. E., \& Toal-Sullivan, D. (2015). Use of the structured interview matrix to enhance community resilience through collaboration and inclusive engagement. Systems Research and Behavioral Science, 32(6), 616-628. http://doi.org/10.1002/sres.2250

Owen, H. (2008). Open space technology: A user's guide (third edition). San Francisco, CA: BerrettKoehler Publishers.

Plato, \& Jowett, B. (2001). Phaedrus. Blacksburg, VA: Virginia Tech.

Prigogine, I., \& Stengers, I. (1984). Order out of chaos: man's new dialogue with nature. Toronto: Bantam Books.

Prime, J., \& Salib, E. R. (2014, February 11). Inclusive Leadership: The View From Six Countries [Text]. Retrieved May 13, 2016, from http://www.catalyst.org/knowledge/inclusive-leadership-viewsix-countries

Quinn, R. E., \& Thakor, A. V. (2014). Chapter 9: Imbue the organization with a higher purpose. In J. E. Dutton \& G. M. Spreitzer (Eds.), How to be a positive leader: small actions, big impact. San Francisco, California: Berrett-Koehler Publishers and Books24X7.

Raelin, J. A. (2003). Creating leaderful organizations: How to bring out leadership in everyone. San Francisco, CA: Berrett-Koehler.

Raelin, J. A. (2006). Taking the charisma out: Teaching as facilitation. Organization Management Journal, "First Person," 3(1), 4-12.

Raelin, J. A. (2014). Imagine there are no leaders: Reframing leadership as collaborative agency. Leadership, 1742715014558076. http://doi.org/10.1177/1742715014558076

Raelin, J. A. (Ed.). (2016). Leadership-as-practice: Theory and application. New York: Routledge.

Rayner, S. (2009). Educational diversity and learning leadership: a proposition, some principles and a model of inclusive leadership? Educational Review, 61(4), 433-447. http://doi.org/10.1080/00131910903404004

Schein, E. H. (1997). The concept of "client" from a process consultation perspective: A guide for change agents. Journal of Organizational Change Management, 10(3), 202-216. http://doi.org/10.1108/09534819710171077 
Schein, E. H. (2013). Humble inquiry: The gentle art of asking instead of telling. San Francisco: BerrettKoehler Publishers and Books24X7.

Schein, E. H. (2015). Foreword: Dialogic organization development: Past, present, and future. In G. Bushe \& R. J. Marshak (Eds.), Dialogic organization development: The theory and practice of transformational change (pp. vii-xiv). San Francisco, CA: Berrett-Koehler Publishers.

Senge, P. M. (1990). The Fifth Discipline: The Art \& Practice of the Learning Organization (1st ed.). New York: Doubleday.

Skjei, S. (2014). Leaders' lived experience of authentic moments. In K. Goldman Schuyler, J. E. Baugher, K. Jironet, \& L. Lid-Falkman (Eds.), Leading with Spirit, Presence, and Authenticity, (pp. 213-231). San Francisco: Jossey-Bass.

Sugiyama, K., Cavanagh, K. V., Esch, C. van, Bilimoria, D., \& Brown, C. (2016). Inclusive leadership development drawing from pedagogies of women's and general leadership development programs. Journal of Management Education, 40(3), 253-292. http://doi.org/10.1177/1052562916632553

Taylor, M. M. (2011). Emergent Learning for Wisdom. New York: Palgrave Macmillan.

Thorpe-Moscon, J. (2015). Inclusion is key to keeping Canadian high potentials (Research Report). Toronto, ON, Canada: Catalyst Research Centers. Retrieved from http://www.catalyst.org/system/files/inclusion_is_key_to_keeping_canadian_high_potentials.p df

UNESCO. (2009). Education and the search for a sustainable future (Policy dialogue: ESD and development policy). (Vol.:1; 2009-179121e). Paris. Retrieved from http://unesdoc.unesco.org/images/0017/001791/179121e.pdf

Van de Ven, A.H. (2011). Engaged scholarship: Stepping out. Business Strategy Review, 2, 43-45.

Vygotsky, L. S. (1986). Thought and Language - Revised Edition (Revised -Original 1962). The MIT Press.

Walinga, J., \& Harris, B. (2016). Chapter 1: From barriers to breakthroughs: Student experiences of the RRU Learning Model. In D. Hamilton, P. Márquez, N. Agger-Gupta, S. Grundy, G. Veletsianos, V. Forssmann, \& M. LeGault (Eds.), Engaging students in life-changing learning: The Royal Roads University learning and teaching model In practice (pp. 33-63). Victoria, BC, Canada: Royal Roads University. Retrieved from https://learningandteachingmodel.pressbooks.com/

Weisbord, M. R. (2012). Productive workplaces: Dignity, meaning, and community in the 21st century (3rd (25th Anniversary) ed.). New York: Pfeiffer and Books24X7. 
Wheatley, M. (2006).Leadership and the New Science: Discovering Order in a Chaotic World. San Francisco: Berrett-Koehler.

Wheatley, M. J. (2002). The work of servant-leadership. In L. C. Spears \& M. Lawrence (Eds.), Focus on Leadership : Servant-Leadership for the Twenty-First Century. New York: Wiley.

Woods, P. A. (2016). Chapter 4: Democratic roots: Feeding the multiple dimensions of leadership-aspractice. In J. A. Raelin (Ed.), Leadership-as-Practice: Theory and Application (pp. 70-87). New York: Routledge.

Zimmerman, B., Reason, P., Rykert, L., Gitterman, L., Christian, J., \& Gardam, M. (2013). Front-line ownership: generating a cure mindset for patient safety. Healthcare Papers, 13(1), 6. 


\section{Author Bios:}

(50-75 word narrative bio of chapter authors)

Niels Agger-Gupta, PhD, is Associate Professor and Program Head of the Graduate Certificate in Leadership at Royal Roads University in Victoria, Canada. A former Program Head, MA-Leadership, Niels maintains his 'orientation to possibility' through supervising Leadership students engaged in transformative capstone projects. Research interests include action research, dialogic change, appreciative inquiry, and group methods, including world café. He holds a PhD in Human and Organizational Systems from Fielding Graduate University (Santa Barbara, California).

Brigitte Harris, PhD, is Professor and Acting Dean of the College of Social and Applied Science at Royal Roads University. She embraces the University's key role of educating, and transforming leaders who can engage others to create positive change. Her research interests include action research and narrative inquiry as a means of engaging others, women in leadership and transformative education. She holds a $\mathrm{PhD}$ from the Ontario Institute for Studies in Education (University of Toronto). 